\title{
ЗАПОЗИЧЕННЯ АНГЛОМОВНИХ АЛЮЗИВНИХ НЕОЛОГІЗМІВ ЯК СТРАТЕГІЯ УКРАЇНСЬКОГО МЕДІА-МОВЛЕННЯ
}

\author{
Ясинецька Н. А. Запозичення англомовних алюзивних неологізмів як стратегія українського \\ медіа-мовлення. \\ У статті розглянуто за тематикою запозичення англомовних алюзивних неологізмів 1990-х - \\ 2000-х років, виявлено різновиди алюзії в них, проаналізовано роль і місце таких запозичень в \\ українській мові. \\ Ключові слова: неологізм, запозичення, алюзія, історична алюзія, філологічна алюзія, подвійна \\ історично-філологічна алюзія.
}

Ясинецкая Н. А. Заимствование англоязычных аллюзивных неологизмов как стратегия украинского медиа-дискурса.

В статье рассмотрены по тематике заимствования англоязычных аллюзивных неологизмов 1990-х - 2000-х годов, выявлены разновидности аллюзии в них, проанализированы роль и место таких заимствований в украинском языке.

Ключевые слова: неологизм, заимствование, аллюзия, историческая аллюзия, филологическая аллюзия, двойная историческо-филологическая аллюзия.

Yasynetska N. A. The borrowing of the English-language allusive neologisms as a strategy of Ukrainian media-discourse.

The article considers thematically the borrowings of the 1990-s - 2000-s' English-language allusive neologisms; the author distinguishes between different types of allusion and analyses the role and place of such borrowings in the Ukrainian language.

Key words: neologism, borrowing, allusion, historic allusion, philological allusion, double historic and philological allusion.

Зовнішні імпульси мовних змін, номінативні й комунікативні потреби зумовлюють інтенсивні модифікації національного лексикону, зокрема появу значної кількості неологізмів, семантичну переорієнтацію лексики й фразеології, зовнішні та внутрішні запозичення до сучасної української літературної мови. Інновації, які забезпечують потреби спілкування відповідно до змін у позамовному середовищі, найчастіше з'являються завдяки письменникам, журналістам, державним і політичним діячам, ученим і дослідникам. Широке коло читачів сприяє тому, що слова, які позначають нові явища й поняття, швидко входять у загальновживану мову, поширюються й адаптуються в ній.

Сучасний стан лексикологічних та лексикографічних досліджень виявляє високий рівень зацікавленості науковців процесами оновлення словника сучасної української літературної мови (Б. М. Ажнюк, Д. Х. Баранник, Д. В. Мазурик, Л. І. Мацько, Н. О. Попова, О. А. Сербенська, О. А. Стишов, Л. В. Струганець). Дослідження українських мовознавців висвітлюють освоєння іншомовних запозичень у наукових терміносистемах (О.А. Лисенко, Г. А. Сергєєва), словотвірне освоєння запозичень (Д. В. Мазурик), лексико-семантичну рецепцію іншомовних слів в українській мові (В. П. Сімонок). Проте в україністиці 
мало уваги приділяється поповненню й оновленню арсеналу лексикостилістичних прийомів та засобів завдяки іншомовним запозиченням.

Оскільки початковим етапом входження запозичень у мовуреципієнт $є$ їх переклад у певному контексті, відтворення алюзій у складі запозичень англомовних неологізмів ми розглядаємо, спираючись на теоретичні моделі та підходи до відтворення алюзії в перекладі, які розробили Л. М. Венуті, В. С. Виноградов, С. І. Влахов, Р. П. Зорівчак, В. Н. Комісаров, С. П. Флорін, О. І. Чередниченко, О. Д. Швейцер. Певних аспектів перекладу алюзї торкалися у своїх працях також Л.В.Грек, О. А. Іванов, Т. Є. Некряч, О. К. Смирнов, О. М. Копильна, О. А. Ясинецька. Водночас, підгрунтям для нашої праці є зіставні дослідження потенціалу та реалізації алюзії в окремих мовленнєвих актах в англійській та українській мовах (О. О. Лавриненко, С. М. Кудиба).

На межі XX-XXI століть потужним джерелом запозичень для української мови залишається англійська, яка, у свою чергу, переживає неологічний бум. Співвідношення логічного та експресивно-оцінного в структурі неологізмів зумовлює необхідність розуміти під комунікативними потребами суспільства не лише прагнення мовців диференційовано по-новому позначати об'єкти і явища, які виникають у результаті розвитку культури, науки й техніки, а й намір висловити оцінку сучасних реалій суспільства, вказуючи на їх подібність, взаємозалежність або суперечливість.

Алюзія - це «натяк на який-небудь мовний, літературний, соціальний факт, звичай, реалію, рису побуту чи традицій» [2, с. 63]. По суті, алюзія є різновидом прихованої інформації в слові, стійкому словосполученні, реченні чи тексті. Прихована інформація в різних мовленнєвих актах не лише впливає на свідомість мовців, а й формує стереотипи поведінки представників етносу. Хоча «кожна мова створює свій «семантичний всесвіт» - тобто $є$ поняття, фундаментальні для людей одного світу й відсутні в іншому» [1, с. 21], - лексичні й семантичні неологізми, як правило, запозичуються разом із поняттями, названими цими словами або словосполученнями [3, с. 47].

Актуальність дослідження алюзії як мовленнєвої стратегії відображення історії та сучасності засобами неології полягає в тому, що алюзія лежить в основі не лише відомих і усталених, а й нових лексичних та фразеологічних одиниць англійської мови, які активно запозичуються українською мовою в сучасних умовах тенденції до глобалізації та євроінтеграції, впливу англійської мови як світової; і ця царина залишається недослідженою. Метою нашої праці $\epsilon$ розглянути за тематикою запозичення англомовних алюзивних неологізмів 1990-х 2000-х років, виявити різновиди алюзії в них, проаналізувати роль і місце таких запозичень в українській мові. 
Як свідчать спостереження, неологізми, запозичені 3 англійської мови, в українській суспільно-політичній періодиці характеризуються неоднаковою частотою, неоднорідністю тематичного, стилістичного й жанрового використання. Тематичні групи неологізмів у засобах масової інформації охоплюють, перш за все, ті галузі, які знаходяться в центрі уваги громадськості [4]. Отже, основними темами, які піднімаються в алюзивних неологізмах 1990-х - 2000-х років, є: міжнародна політика розподілу влади й сфер впливу, міжнародні конфлікти й спричинені ними трагедії, науково-технологічні відкриття та їх наслідки для сучасного повсякдення, а також вплив інформаційних засобів на масовість уподобань суспільства споживачів.

Алюзія може стосуватися як філологічної інформації (філологічний вертикальний контекст), так i реальності минулого чи теперішнього (соціальний або подвійний вертикальний контекст) [2, с. 42]. Уточнивши й розширивши класифікацію В.С. Виноградова, ми виділяємо такі різновиди алюзії: 1) історична алюзія; 2) філологічна алюзія; 3) подвійна історичнофілологічна алюзія. За нашими спостереженнями, найрідше у досліджуваних неологізмах зустрічаються ізольовано філологічні алюзії. У більшості випадків вони все ж пов'язані із соціально-історичними реаліями. Звернення до міфологічних i біблійних фактів вважаємо філологічно-історичними алюзіями, й лише приховане посилання на суто художні твори чи літературних персонажів відносимо до філологічної алюзіï.

1. Історична алюзія.

3 початку 1990-х років увага міжнародної спільноти була прикута до тривалого конфлікту між Сполученими Штатами й Іраком, значною мірою спричиненого прагненням США відстоювати власні позиції у відношенні нафтових родовищ та міжнародної впливовості. Реалії цього міжнародного конфлікту загальновідомо позначаються англомовними неологізмами сучасності. Новими стійкими словосполученнями, які не містять філологічної алюзіï, є Gulf war - війна в (Перській) затоцуі «воєнні дії США та їх союзників з НАТО проти Іраку в районі Перської затоки в 1991 році» i desert storm - буря в пустелі «кодова назва воєнних дій США й союзників з НАТО проти Іраку в 1991 році»: Збільшений дрейф пісків був одним із ефектів, помічених під час і після першої війни в Затоці (День, 18.04.2003); За час перебування на посаді керує військовими кампаніями у Панамі й операцією «Буря в пустелі» на Близькому Сході (Народна правда, 19.07.2007).

Алюзіями до терористичного акту Іраку проти США 11 вересня 2001 року, який виявився в авіанападі на Всесвітній торговий центр у НьюЙорку і Пентагон у Вашингтоні, є неологізми September 11 plot - mеракm 11 вересня; black Tuеsday - чорний вівторок; 9/11 (9-11, 9.11, nine-one-one, nine-eleven) - (nодіï) 11 вересня; post-Manhattan reality - постмангетенська 
реальність: США переживає чергове "11 вересня» (For-ua, 15.06.2010 // http://ua.for-ua.com/world/2010/06/15/085801.html); Трагічні подіі «чорного вівторка» 11 вересня 2001 року ... (Дзеркало тижня, 22-28.12.2001); Постманхетенська реальність кардинально змінила основні вісі мегаризиків у бік превалювання політико-антропологічних, гуманітарних чинників (День, 01.12.2001).

Результати геополітичних прагнень засвідчуються в неологізмах, які позначають реформи щодо територіального розподілу: наприклад, balkanization - балканізація «поділ регіону на менші, часто ворожі одна одній громади» (алюзія до роздрібнення держав на Балканському півострові, таких як колишня Югославія, а раніше Австро-Угорщина): Майбутній прем'єр-міністр Великобританії, нещзодавно попередив своїх співгромадян про загрозу «балканізації» країни (Дзеркало тижня, 1218.05.2007); Але чи буде такий розвиток подій в інтересах самої Росії $з$ огляду на те, як далеко зайшла балканізачія Північного Кавказу? (Дзеркало тижня, 01-07.12.2007).

2. Філологічна алюзія.

Деякі науково-технологічні відкриття мають позитивно-пізнавальні наслідки для сучасності, наприклад: Goldilocks planet - nланета Золотоволоска «планета, на якій можливе життя, оскільки вона не надто гаряча й помірно холодна, не дуже велика й не зовсім маленька, не надто наближена до своєї зірки й не дуже віддалена від неї» (алюзія до казкового персонажа - дівчини-золотоволоски): Пошуки учених сконцентровані в основному в так званій «зоні Золотоволоски»- сегменті космосу, де планети знаходяться на необхідній відстані від своїх зірок, тобто вони не дуже холодні і не дуже гарячі, щзоб там могла існувати вода в рідкому вигляді (Новини NEWSru.ua, 20.03.2008 // http:/www.newsru.ua/world/ 20mar2008/organika.html).

Сумніви щодо безпечності й користі для здоров'я харчових продуктів, які є модифікованими чи отриманими штучно, шляхом генної інженерії, перетворилися на очевидну занепокоєність наслідками такого наукового втручання, що простежується на прикладі неологізму Frankenstein food - «їжа Франкенштейна» (алюзія до створення монстра в результаті наукового експерименту молодого вченого Генрі Франкенштейна 3 класичного науково-фантастичного фільму жахів Джеймса Вейла, екранізованого в 1931 році за романом «Франкенштейн» Мері Шеллі та написаній за його мотивами п'єсі Пеггі Веблінг): Вони проходять систему перевірок $і$ тестування $i$ зовсім не схожі на «їжу Франкенштейна» (Україна молода, 29.02.2008).

3. Подвійна історично-філологічна алюзія.

Поєднання алюзії до філологічної та історичної інформації ілюструють, зокрема, такі неологізми в галузі міжнародної політики: cold peace - холодний мир «фактично ворожі стосунки без ідеологічного 
запалу» (алюзія до словосполучення cold war - холодна війна, терміна, що позначав геополітичну й ідеологічну боротьбу між СРСР і Сполученими Штатами після Другої світової війни, 3 1948-го року до розпаду Радянського блоку в 1989 році): Холодна війна, холодний мир, ознаки відновлення холодної війни, а згодом знову обічянка миру. Чи існує якась логіка у розвитку відносин між США та Росією? (День, 22.09.2009); electronic curtain - електронна завіса «обмеження в існуванні транскордонних 3МI 3 метою нерозголошення реального стану речей в електронній мережі» (алюзія до словосполучення iron curtain - залізна завіса, терміна часів «холодної війни», що означав в основному ідеологічно нездоланну ізоляцію країн Варшавського договору під проводом СРСР від країн Заходу під егідою США): Електронна завіса колективної ідентичности (Критика, 2008, № 6 (80)).

Алюзія до філологічної інформації нерідко передбачає утворення неологізму за аналогією до вже існуючого слова або стійкого словосполучення. Подвійна філологічно-історична алюзія простежується й на прикладі терміна axis of evil - «вicb зла» «країни, які підтримують співпрацю з тероризмом», який створили автори промови Девід Фрум та Майкл Карден на основі алюзії до словосполучення Axis powers - держави oci «Німеччина та іiі союзники Італія і Японія в Другій світовій війні»: «Вісь зла», до якої президент США Джсордж Буш зарахував Північну Корею, Іран та Ірак, поповнилася трьома новими краӥнами (День, 08.05.2002).

Історична й філологічна алюзія до політичного скандалу 3 підслуховуванням на політичному грунті в готелі Watergate у Вашингтоні призвела до появи в англійській та адаптації в українській мові префіксального компонента -gate - -лейm, який вже навіть лексикалізовано самостійно означає «скандал, зокрема політичний»: ... поява чергового «ㄹеита» на колонках вищезгаданих видань буде сигналом для порушення кримінальних справ (День, 14.11.1998); Вотергейт, Монікагейт, Гор-гейт? (День, 27.06.2000); Справа Гонгадзе $i$ «мейптейт» ... (Дзеркало тижня, 0107.04.2001); Про цүю перспективу ніхто серйозно не говорить з осені минулого року - часу початку так званого "кучмагейту» (Дзеркало тижня, 11-17.08.2001).

Прояв економічних реформ у світі засвідчує алюзія до ленінізму як уособлення планової/командної моделі економіки: Market-Leninism ринковий ленінізм «економічна система, яка об'єднує аспекти як капіталізму, так і комунізму» (філологічна алюзія до Marxism-Leninism): Тим часом, багато аналітиків передбачають рух до нового впровадження капіталізму в сучасному китайському чи в'єтнамському варіанті авторитарного ринкового ленінізму (Commons/Спільне (журнал соціальної критики), 30.04.2010 // http://commons.com.ua/archives/2154). 
Про формування масовості суспільних уподобань під впливом інформаційних засобів свідчить неологізм-алюзія weapon of mass distraction - зброя масового відволікання (уваги) «те, що відволікає багатьох людей від думок про важливі речі» (алюзія до словосполучення weapon of mass distruction - зброя масового ураження): "Дослідіть зброю масового відволікання уваги» закликає ия реклама, граючи словами destruction (знищення) $i$ distraction (відволікання) (Українська правда, 09.05.2008).

Стійке словосполучення big bang - великий вибух у новому значенні «радикальні реформи/зміни» $\epsilon$ алюзією до фізико-космологічної Теорії великого вибуху (Big Bang Theory), згідно з якою Всесвіт виник із надзвичайно щільного та гарячого стану приблизно 13,7 мільярдів років тому. Філологічна алюзія полягає в покликанні на існуюче стійке словосполучення, яке наразі зазнає семантичної неологізації: Таким «Великим Вибухом» для Київської Руси стала смерть Володимира Мономаха в 1125 рочі. Саме після неї удільні князівства починають у вільному парінні свій відиентровий рух (Народна правда, 24.07.2009).

Прикрі наслідки технологічних розробок віддзеркалює, наприклад, стійке словосполучення Troyan horse (program) - «троянський кінь», «троянець» у новому значенні «шкідницька гакерська комп'ютерна програма»; цей неологізм $\epsilon$ алюзією до грецького міфу про перемогу греків при облозі Трої: "Троянський кінь» - ие програма, замаскована під комериійний продукт, але виконує зовсім не ті дії, на які можна очікувати (Хрещатик, 21.01.2010); “Троянеиь» шифрував імена усіх файлів, робив їх невидимими $i$ залишав на диску лише один файл ... (Дзеркало тижня, 02.02.2002); На арену виходять численні троянські програми, щэо крадуть nаролі доступу в Інтернет (Дзеркало тижня, 02.02.2002).

Деякі англомовні неологізми та їх відповідники-запозичення в українській мові ілюструють подвійну алюзію до історичних подій та лінгвокультурологічних фактів, тобто культури та традицій окремих народів. Так, економічні події на міжнародному рівні 3 очевидним прогресом впливовості азійських держав закріпили за останніми метафоричні назви, які вже використовуються як загальноприйняті міжнародні алюзії до країн азіатсько-тихоокеанського регіону: Asian tiger (азійський/азіатський) тигр «нова індустріальна країна Південно-Східної Азії з високими темпами розвитку» і dragon - (азійський/азіатський) «дракон» «нова промислово розвинена країна в Східній Азії». Така метафоризація $\epsilon$ своєрідною алюзією до символів, які певним чином уособлюють культуру відповідних держав: Змагання за «азійських тигрів» (День, 01.02.2005); Зате, рівняючись на «тигрів», терміни можна скоротити до 10-30 років (Дзеркало тижня, 12.04.2007); Криза азіатських драконів (Контракти, 15.06.2009); Але апофеозом появи нових варварів, $\epsilon$ звичайно китайський дракон, який пожре $і$ азійських тигрів, $і$ російського 
ведмедя, $і$ американського єнота, $і$ європейського вовка, $і$ украӥнського хом'яка (Український богословський сайт, 08.10.2009 // http://www.theology.kiev.ua/article.php?cid=14\&aid=82\&smIndex=0).

Як вже згадувалося, серед найбільших негараздів сучасності, які навіть загрожують невиліковними хворобами та вимиранням людства й потребують негайного втручання й виправлення ситуації, знаходиться споживання «швидкої» їі та генетично-модифікованих продуктів харчування, прикладом чого $є$ неологізм farmageddon (farmaceutical + armageddon) - фармагедон (алюзія до слова Армагедон, що запозичене 3 єврейської і в Біблії згадується як «гора Мегіддо» або «гора збору військ» та пов'язується $з$ апокаліптичним знищенням, коли ангели виливали «сім чаш гніву Божого»): Вони вважають, щзо якщзо не змінити діючі правила контролю застосування нових біотехнологій на полях США, то країну чекає формагедон (Поступ, 18.07.2003 // htp postup.brama.com/usual.php? what =11998).

Очевидно, що в публіцистиці, яка спирається на нові мовні тенденції та керується позамовними чинниками, розкриття внутрішнього змісту англомовних неологізмів-алюзій за допомогою їх калькування засобами української мови дає змогу виявити ті закономірності, які лежать в основі особливостей мовно-когнітивного позначення суспільно-політичних реалій міжнародного значення на поточному етапі розвитку англійської та української мов. Перспективними вважаємо дослідження когнітивних параметрів, механізмів творення й прагматично-комунікативного призначення алюзивних неологізмів в українській мові.

\section{Література}

1. Вежбицкая А. Язык. Культура. Познание / Анна Вежбицкая. - М. : Рус. словари, 1996. - 416 с.

2. Виноградов В. С. Перевод. Общие и лексические вопросы : учеб. пособие. / Венедикт Степанович Виноградов. - [3.-е изд.] - М. : Книжный дом «Университет», 2006. - 237 с.

3. Сімонок В. П. Лексико-семантична рецепція іншомовної лексики в українській мовній картині світу : дис. ... д-ра філол. наук : 10.02.01 / Сімонок Валентина Петрівна. - Х., 2001. - 478 с.

4. Швейцер А. Д. Опыт контрастивного стилистического анализа языка русских и американских средств массовой информации / А. Д. Швейцер // Филологические науки. - 1994. - № 1. - С. $103-109$. 